See Article page e159.

\section{Commentary: Go small or go home}

\author{
Anthony W. Kim, MD, ${ }^{a}$ and Usman Ahmad, MD ${ }^{\mathrm{b}}$
}

At the start of 2020, it will have been nearly 1 decade shy of a century since malignant pleural mesothelioma (MPM) was recognized as its own disease. ${ }^{1}$ Its first appearance in the Journal was in 1959, and even then it appears that the entity that later would become known as MPM remained incompletely accepted universally. ${ }^{2}$ The inadequate efficacy of radiation therapy and chemotherapy at that time resulted in the conclusion that radical surgical extirpation was the only way to "salvage" patients. In many ways since then, as the saying goes, the more things have changed the more they have stayed the same. Although radical resection in the form of pleural pneumonectomy is still necessary at times, cytoreductive surgery with pleurectomy and decortication is becoming more widely accepted and the preferred approach. Surgical intervention, although not performed in isolation, remains an important part of the multimodal approach to this complex disease. Exactly what modalities should comprise multimodal therapy in MPM is the subject of intense investigation, such as by $\mathrm{Chu}$ and colleagues ${ }^{3}$ in this issue of the Journal.

In a murine model in which cell lines of mesothelioma were injected into the pleural space, Chu and colleagues ${ }^{3}$ evaluated the efficacy of paclitaxel-loaded $\mathrm{pH}$-responsive expansile nanoparticles in treating early and late stages of MPM. In their early stage model, the pure therapeutic efficacy of these paclitaxel-loaded $\mathrm{pH}$-responsive expansile nanoparticles was shown clearly through a doubling of the overall survival. In an effort to mimic treating the more typical clinical presentation of MPM, their late stage model was associated with a greater tumor burden and used surgery as a part of a multimodal approach.

\footnotetext{
From the a Division of Thoracic Surgery, Keck School of Medicine, University of Southern California, Los Angeles, Calif; and ${ }^{\mathrm{b}}$ Thoracic Surgery, Heart and Vascular Institute, Cleveland Clinic, Cleveland, Ohio.

Disclosures: Authors have nothing to disclose with regard to commercial support.

Received for publication Jan 7, 2020; revisions received Jan 7, 2020; accepted for publication Jan 13, 2020; available ahead of print Jan 31, 2020.

Address for reprints: Anthony W. Kim, MD, Jeffrey P. Smith Endowed Chair in Surgery, Division of Thoracic Surgery, Keck School of Medicine, University of Southern California, 1510 San Pablo St, Suite 514, Los Angeles, CA 90033 (E-mail: anthony.kim@med.usc.edu).

J Thorac Cardiovasc Surg 2020;160:e173-4 $0022-5223 / \$ 36.00$

Copyright $(2020$ Published by Elsevier Inc. on behalf of The American Association for Thoracic Surgery

https://doi.org/10.1016/j.jtcvs.2020.01.036
}

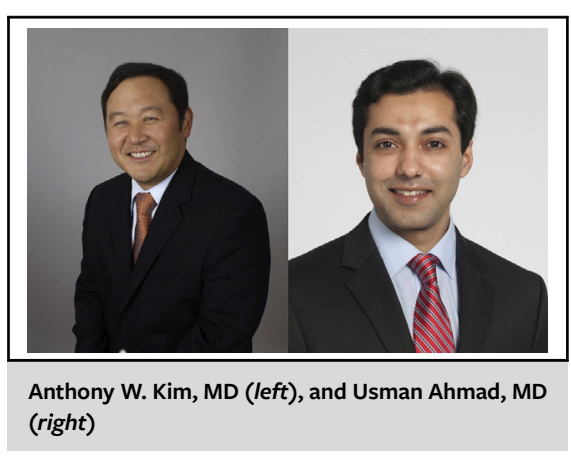

CENTRAL MESSAGE

The benefits of nanoparticle therapy observed in the murine model of malignant pleural mesothelioma are both pioneering and foundational.

The median overall survival of those mice undergoing paclitaxel-loaded $\mathrm{pH}$-responsive expansile nanoparticle therapy followed by surgery was greater than for those mice receiving chemotherapy alone by an astounding $126 \%$. If even a fraction of this effect observed in mice were to be replicated in humans, it would represent a paradigm shift. The median survival for patients with MPM undergoing trimodality therapy has ranged from 15 to 18 months. ${ }^{4,5}$ A $126 \%$ improvement would translate into median overall survivals of 34 to 41 months, which would place the outcomes associated with MPM in the same realm as those of other malignancies associated with pleural involvement. In fact, this type of intervention could also open the possibility of treating even secondary pleural-based malignancies with this novel therapeutic strategy, possibly changing the landscape of how we manage all thoracic malignancies with pleural involvement.

The work of Chu and colleagues ${ }^{3}$ in the Colson Laboratory with nanoparticles in the treatment of MPM is both pioneering and foundational. It will be exciting to see how their work meshes with the evolving field of immunotherapy, including other adoptive cellular therapies such as chimeric antigen receptor T-cell therapy and tumor-infiltrating lymphocyte therapy. As 
surgeons who are deeply invested in moving the proverbial needle, we eagerly await more scientific data describing this interplay from their laboratory. In the course of time and through the work of our colleagues, "going big" in the efforts to modernize MPM therapy may actually mean going small or smaller-nanoparticle smaller!

\section{References}

1. Klemperer P, Rabin CB. Primary neoplasms of the pleura. Arch Pathol. 1931;11: 385-412.
2. Kahn DS, Glay A, Madore P. Malignant pleural mesothelioma: a case report with autopsy findings. J Thorac Cardiovasc Surg. 1959:38:225-34.

3. Chu NQ, Liu R, Colby A, de Forcrand C, Padera RF, Grinstaff MW, et al. Paclitaxel-loaded expansile nanoparticles improve survival following cytoreductive surgery in pleural mesothelioma xenografts. J Thorac Cardiovasc Surg. 2020; 160:e159-68.

4. Baldini EH, Richards WG, Gill RR, Goodman BM, Winfrey OK, Eisen HM, et al. Updated patterns of failure after multimodality therapy for malignant pleural mesothelioma. J Thorac Cardiovasc Surg. 2015;149:1374-81.

5. de Perrot M, Wu L, Cabanero M, Perentes JY, McKee TD, Donahoe L, et al. Prognostic influence of tumor microenvironment after hypofractionated radiation and surgery for mesothelioma. J Thorac Cardiovasc Surg. November 13, 2019 [Epub ahead of print]. 